\title{
Lipase Catalysed Kinetic Resolution of Stiripentol
}

\author{
Elisabeth Egholm Jacobsen (Corresponding author) \& Thorleif Anthonsen
}

Department of Chemistry, Norwegian University of Science and Technology

Trondheim N-7491, Norway

Tel: 47-98-843-559 E-mail: elis-jac@online.no

Mohammed Farrag El-Behairy \& Eirik Sundby

Department of Chemistry and Materials Science, Sør-Trøndelag University College

Trondheim N-7004, Norway

Tel: 47-73-559-645 E-mail: eirik.sundby@hist.no

Mohamed Nabil Aboul-Enein, Mohamed Ibrahim Attia \& Aida Abd El-Sattar El-Azzouny

Medicinal and Pharmaceutical Chemistry Department, Pharmaceutical and Drug Industries Research Division

National Research Centre, Dokki, Giza 12622, Egypt

Kamilia M. Amin

Department of pharmaceutical Chemistry, Faculty of Pharmacy, Cairo University

Kasr El-Aini, Cairo 11562, Egypt

E-mail: cameliaamin@yahoo.com

Mohamed Abdel-Rehim

Department of Analytical Chemistry, Stockholm University

Stockholm SE-106 91, Sweden

E-mail: mohamed.abdel-rehim@anchem.su.se

Received: October 27, $2011 \quad$ Accepted: November 21, $2011 \quad$ Published: February 1, 2012

doi:10.5539/ijc.v4n1p7

URL: http://dx.doi.org/10.5539/ijc.v4n1p7

The research is financed by The Research Council of Norway. Contract grant number: 202903/11

\begin{abstract}
Kinetic resolution of rac-Stiripentol, catalysed by lipase A from Candida antarctica by esterification with vinyl butanoate was performed with an E-value of 24. This allowed isolation of (3S)-Stiripentol with an ee of $86 \%$ and the corresponding (3R)-butanoate with an ee of $87 \%$. Enzymatic hydrolysis of the ester product gave (3R)-Stiripentol with $94 \%$ ee.
\end{abstract}

Keywords: Kinetic resolution, Stiripentol enantiomers, Candida antarctica lipase A, Chiral HPLC

\section{Introduction}

Stiripentol, rac-1-(benzo[d][1,3]dioxol-5-yl)-4,4-dimethylpent-1-en-3-ol (rac-1) is a novel antiepileptic drug structurally unrelated to any other antiepileptic drugs. It has been suggested that Stiripentol induced increase in gamma amino butanoic acid (GABA) concentration through at least two independent neurochemical mechanisms (Trojnar et al., 2005). Recently, it was reported that Stiripentol acts directly on the $\mathrm{GABA}_{\mathrm{A}}$ receptor as a positive allosteric modulator (Fischer et al., 2009). In addition, its anticonvulsant potency had been proven 
in different types of animal seizures, as well as in clinical trials (Chiron, 2005). Stiripentol is a secondary alcohol containing one stereogenic center. So far, it is marketed as a racemic mixture, albeit, there are marked differences in pharmacokinetics and antiepileptic potency between the enantiomers (Trojnar et al., 2005).

It is well known that enantiomers of a racemic drug may have different pharmacokinetic and pharmacodynamic effects. The body will interact with and metabolise each enantiomer differently to produce different pharmacological activities. Thus, one isomer (eutomer) may produce the desired therapeutic activities, while the other (distomer) may be inactive or, in worst cases, produce unwanted negative effects (Sheldon, 1993). US Food and Drug Administration (FDA) considers one enantiomer (distomer) as an impurity of the other enantiomer (eutomer). This requires independent investigations of both enantiomers of chiral drugs. Therefore, development of new analytical and preparative techniques to obtain pure enantiomers has become of particular importance for pharmaceutical industry (Collins et al., 1992; Collins et al., 1997).

Resolution is one of the major strategies for providing enantiopure chiral building blocks (CBB's) for drug synthesis. Enzyme catalysed kinetic resolution is a common method in order to obtain CBB's. Enzymes are remarkable catalysts, capable of accepting a wide range of substrates, at the same time exhibiting chemo-, regio-, and enantio-selectivity (Fessner et al., 2009; Bommarius et al., 2004). Moreover, the availability and low price of most classes of enzymes have significantly made them more economically attractive catalysts for the production of biologically active compounds. Hydrolytic enzymes, in particular lipases, are most commonly used as biocatalysts for enzymatic resolution. Most lipases accept a broad range of non-natural substrates and are thus very versatile for applications in organic synthesis. They do not require cofactors and are commercially available in free and immobilised forms. In many cases, they exhibit good to excellent stereoselectivity (Bornscheuer et al., 2005).

\section{Experimental}

\subsection{General}

All solvents used were analytical grade (p.a.) and purchased from Sigma-Aldrich (Steinheim, Germany). Immobilized Candida antarctica lipase B (Novozym 435, activity 10000 PLU/g, lot no. LC 200205) was bought from Novozymes (Bagsværd, Denmark). Lipase A from Candida antarctica immobilized on Immobead 150, (activity $500 \mathrm{U} / \mathrm{g}$, lot no. 1388471) was bought from Sigma-Aldrich.

${ }^{1} \mathrm{H}-\mathrm{NMR}$ spectra were carried out on Jeol 500 and Bruker $400 \mathrm{MHz}$ spectrophotometers using TMS as an internal standard. Chemical shift values are recorded in ppm $\delta$ scale. Optical rotations $\left([\alpha]_{\mathrm{D}}\right)$ were determined at $20{ }^{\circ} \mathrm{C}$ using a Perkin-Elmer 341 instrument, concentrations are given in $\mathrm{g} / 100 \mathrm{~mL}$. All melting points are uncorrected and measured by an Electrothermal Capillary melting point apparatus. A IKA KS 4000 shaker incubator was used for the enzyme reactions. Enantiomeric ratios, $E$, were calculated based on ping-pong bi-bi kinetics using the computer program E \& K Calculator 2.1b0 PCC (Anthonsen et al., 1996) based on the calculations of Chen and Rakels. (Chen et al., 1982; Rakels et al., 1994).

\subsection{Chiral chromatography analyses}

All compounds were separated on an Agilent 1100 HPLC system (Agilent, USA) with a quaternary pump and a variable wavelength UV detector and equipped with Chiracel OD- ${ }^{\circledR}$ column ([cellulose tris (3,5 dimethylphenylcarbamate) coated on $5 \mu \mathrm{m}$ silica-gel], i.d. $4.6 \mathrm{~mm}, 25 \mathrm{~cm}$, film density $5 \mu \mathrm{m}$ ). n-Hexane, tert-butyl methyl ether (MTBE) and 2-propanol (2-PrOH) were used as eluents, flow rate $1 \mathrm{~mL} \mathrm{~min}^{-1}$. Retention times: Stiripentol butanoate enantiomers (mobile phase 95:5:1): (S)-2: $5.0 \mathrm{~min},(R)-2): 5.4 \mathrm{~min}, R_{S}$ 1.76. Alcohol enantimers same run: (R)-1: $27.9 \mathrm{~min},(S)-\mathbf{1}: 30.3 \mathrm{~min}, R_{S}$ 1.93. Stiripentol acetate enantiomers (mobile phase 95:5:2): (S)-3: $4.15 \mathrm{~min},(R)-3: 4.45 \mathrm{~min}, R_{S}$ 1.8. Alcohol enantiomers same run: (R)-1: $17.7 \mathrm{~min},(S)-1: 19.0 \mathrm{~min}$, $R_{S}$ 1.55. Stiripentol propanaote enantiomers (mobile phase 95:5:1): (S)-4: 5.2 min, (R)-4: $5.6 \mathrm{~min}, R_{S} 2.14$. Alcohol enantiomers same run: (R)-1: $27.8 \mathrm{~min},(S)-\mathbf{1}: 30.1 \mathrm{~min}, R_{S} 1.84$.

\subsection{Synthesis of substrates}

\subsection{1 rac-(E)-1-(benzo[d][1,3]dioxol-5-yl)-4,4-dimethylpent-1-en-3-ol (1) Stiripentol}

To an ice cooled, stirred solution of (E)-1-(benzo[d][1,3]dioxol-5-yl)-4,4-dimethylpent-1-en-3-one (10 g, 0.043 mol) in methanol $(100 \mathrm{~mL}), \mathrm{NaBH}_{4}(4.9 \mathrm{~g}, 0.13 \mathrm{~mol})$ was added portion wise. The mixture was stirred overnight at ambient temp. followed by addition of water and evaporation. The residue was dissolved in diethyl ether/water and the organic layer was separated, dried $\left(\mathrm{Na}_{2} \mathrm{SO}_{4}\right)$ and evaporated to afford $10 \mathrm{~g}(99 \%)$ of crude rac-1 which was recrystallised from 2-propanol to afford $8.0 \mathrm{~g}\left(79 \%\right.$ ) of pure rac-1 as colorless crystals, $\mathrm{mp} 72{ }^{\circ} \mathrm{C}$. (Vallet, 1975) ${ }^{1} \mathrm{H}-\mathrm{NMR}\left(500 \mathrm{MHz}, \mathrm{CDCl}_{3}\right) 0.94$ (s, 9H, tert-butyl), 2.5 (s, $\left.1 \mathrm{H}, \mathrm{OH}\right), 3.88(\mathrm{~d}, J=7.65 \mathrm{~Hz}, 1 \mathrm{H}, \mathbf{C H O H})$, $5.94\left(\mathrm{~s}, 2 \mathrm{H}, \mathbf{O C H}_{2} \mathrm{O}\right), 6.1(\mathrm{dd}, J=15.3,7.65 \mathrm{~Hz}, 1 \mathrm{H}, \mathbf{C H}=\mathrm{CHPh}), 6.47(\mathrm{~d}, J=15.3 \mathrm{~Hz}, 1 \mathrm{H}, \mathrm{CH}=\mathbf{C H P h}), 6.74$ 
(d, $J=7.65 \mathrm{~Hz}, 1 \mathrm{H}, \mathrm{H}-1), 6.8$ (d, $J=7.65 \mathrm{~Hz}, 1 \mathrm{H}, \mathrm{H}-2), 6.92$ (s,1H, H-3). IR (KBr pellet) 3554, (OH).

2.3.2 General procedures for synthesis of racemic (E)-1-(benzo[d][1,3]dioxol-5-yl)-4,4-dimethylpent-1-en-3-ol esters (rac-2, rac-3, and rac-4)

To a stirred solution of rac-1 $(1.0 \mathrm{~g}, 0.004 \mathrm{~mol})$ in pyridine $(30 \mathrm{~mL})$ was added acetic anhydride $(1.2 \mathrm{~mL}, 1.3 \mathrm{~g}$, $0.012 \mathrm{~mol})$, propanoic anhydride $(1.62 \mathrm{~mL}, 1.65 \mathrm{~g}, 0.012 \mathrm{~mol})$ or butanoic anhydride $(1.95 \mathrm{~mL}, 1.89 \mathrm{~g}, 0.012$ mol). The mixture was refluxed overnight, cooled, poured over $\mathrm{HCl}(200 \mathrm{~mL}, 10 \%$ aq. $)$ and extracted with diethyl ether $(2 \times 50 \mathrm{~mL})$. The ethereal layer was separated, dried $\left(\mathrm{Na}_{2} \mathrm{SO}_{4}\right)$ and evaporated to afford $1.0 \mathrm{~g}$ of crude rac-(E)-1-(benzo[d][1,3]dioxol-5-yl)-4,4-dimethylpent-1-en-3-yl butanoate (Stiripentol butanoate, rac-2), rac-(E)-1-(benzo[d][1,3]dioxol-5-yl)-4,4-dimethylpent-1-en-3-yl acetate (Stiripentol acetate, rac-3) and rac-(E)-1-(benzo[d][1,3]dioxol-5-yl)-4,4-dimethylpent-1-en-3-yl propanoate (Stiripentol propanoate, rac-4). The crude esters were purified by column chromatography using neutral alumina grade 3 and pet. ether $60-80: \mathrm{CHCl}_{3}$ (1:1) to afford $0.8 \mathrm{~g} \mathrm{(62 \% )} \mathrm{of} \mathrm{brown} \mathrm{oil} \mathrm{pure} \mathrm{rac-2,} 0.5 \mathrm{~g} \mathrm{(42 \% )}$ of brown oil of pure rac-3 and $0.6 \mathrm{~g}(48 \%)$ of yellowish brown oil of pure rac-4.

rac-(E)-1-(benzo[d][1,3]dioxol-5-yl)-4,4-dimethylpent-1-en-3-yl butanoate (rac-2). ${ }^{1} \mathrm{H}-\mathrm{NMR}\left(400 \mathrm{MHz}, \mathrm{CDCl}_{3}\right)$ of 0.96 (s, 9H, $t$-butyl), 0.96 (t, $\left.J=7.91 \mathrm{~Hz}, 3 \mathrm{H}, \mathrm{OCOCH}_{2} \mathrm{CH}_{2} \mathbf{C H}_{3}\right), 1.7\left(\mathrm{~m}, 2 \mathrm{H}, \mathrm{OCOCH}_{2} \mathbf{C H}_{2} \mathrm{CH}_{3}\right), 2.0(\mathrm{t}, J=$ $\left.7.16 \mathrm{~Hz}, 2 \mathrm{H}, \mathrm{OCOCH}_{2} \mathrm{CH}_{2} \mathrm{CH}_{3}\right), 5.13(\mathrm{~d}, J=7.91 \mathrm{~Hz}, 1 \mathrm{H}, \mathbf{C H O C O}), 5.94\left(\mathrm{~s}, 2 \mathrm{H}, \mathbf{O C H}_{2} \mathrm{O}\right), 6.0$ (dd, $J=16.2$, $7.9 \mathrm{~Hz}, 1 \mathrm{H}, \mathbf{C H}=\mathrm{CHph}), 6.5(\mathrm{~d}, J=16.2 \mathrm{~Hz}, 1 \mathrm{H}, \mathrm{CH}=\mathbf{C H p h}), 6.74(\mathrm{~d}, J=7.65 \mathrm{~Hz}, 1 \mathrm{H}, \mathrm{H}-\mathrm{Ar}), 6.8(\mathrm{dd}, J=7.65$, $1.51 \mathrm{~Hz}, 1 \mathrm{H}, \mathrm{H}-\mathrm{Ar}), 6.9$ (d, $J=1.51 \mathrm{~Hz}, 1 \mathrm{H}, \mathrm{H}-\mathrm{Ar})$.

rac-(E)-1-(benzo[d][1,3]dioxol-5-yl)-4,4-dimethylpent-1-en-3-yl acetate (rac-3). (Casanova et al., 1972) ${ }^{1} \mathrm{H}-\mathrm{NMR}\left(500 \mathrm{MHz}, \mathrm{CDCl}_{3}\right) 0.94$ (s, 9H, tert-butyl), $2.0\left(\mathrm{~s}, 3 \mathrm{H}, \mathrm{OCOCH}_{3}\right), 5.1(\mathrm{~d}, J=7.65 \mathrm{~Hz}, 1 \mathrm{H}, \mathbf{C H O C O})$, $5.93\left(\mathrm{~s}, 2 \mathrm{H}, \mathrm{OCH}_{2} \mathrm{O}\right), 5.96(\mathrm{dd}, J=16.05$ and $7.65 \mathrm{~Hz}, 1 \mathrm{H}, \mathbf{C H}=\mathrm{CHPh}), 6.49(\mathrm{~d}, J=16.05 \mathrm{~Hz}, 1 \mathrm{H}, \mathrm{CH}=$ CHPh), $6.73(\mathrm{~d}, J=7.65 \mathrm{~Hz}, 1 \mathrm{H}$, aromatic), 6.79 (d, $J=7.65 \mathrm{~Hz}, 1 \mathrm{H}$, aromatic), 6.91 (s, 1H, aromatic).

rac-(E)-1-(benzo[d][1,3]dioxol-5-yl)-4,4-dimethylpent-1-en-3-yl propanoate (rac-4). ${ }^{1} \mathrm{H}-\mathrm{NMR} \quad(500 \mathrm{MHz}$, $\left.\mathrm{CDCl}_{3}\right) 0.94$ (s, 9H, tert-butyl), $1.15\left(\mathrm{t}, J=7.65,7.65 \mathrm{~Hz}, 3 \mathrm{H}, \mathrm{OCOCH}_{2} \mathbf{C H}_{3}\right), 2.0\left(\mathrm{~m}, 2 \mathrm{H}, \mathrm{OCOCH}_{2} \mathrm{CH}_{3}\right), 5.13$ $(\mathrm{d}, J=7.65 \mathrm{~Hz}, 1 \mathrm{H}, \mathbf{C H O C O}), 5.93\left(\mathrm{~s}, 2 \mathrm{H}, \mathrm{OCH}_{2} \mathrm{O}\right), 5.98(\mathrm{dd}, J=16.05$, and $7.65 \mathrm{~Hz}, 1 \mathrm{H}, \mathbf{C H}=\mathrm{CHPh}), 6.49(\mathrm{~d}$, $J=16.05 \mathrm{~Hz}, 1 \mathrm{H}, \mathrm{CH}=\mathbf{C H p h}), 6.73(\mathrm{~d}, J=7.65 \mathrm{~Hz}, 1 \mathrm{H}$, aromatic), $6.8(\mathrm{~d}, J=7.65 \mathrm{~Hz}, 1 \mathrm{H}$, aromatic), 6.9 (s, $1 \mathrm{H}$, aromatic).

\subsection{Small-scale lipase catalysed reactions}

\subsubsection{Transesterification of stiripentol}

Racemic Stiripentol (rac-1) (10 mg, $0.042 \mathrm{mmol})$, acyl donor ( $0.12 \mathrm{mmol}, 3$ equiv.) and $2.0 \mathrm{~mL}$-hexane were added and stirred in a $4 \mathrm{~mL}$ reaction vial. Lipase A from Candida antarctica (CALA) (200 mg) was added and the reaction mixture was thermostated at $35{ }^{\circ} \mathrm{C}$. Samples $(10 \mu \mathrm{L})$ were withdrawn, filtered, diluted to $1 \mathrm{~mL}$ and injected on HPLC column at several time intervals. Several other lipases were used, however only CALA showed enantioselectivity. Of the acyl donors used, (ethylmethoxy acetate, isopropenyl acetate, vinyl benzoate, vinyl propanoate and vinyl butanoae) vinyl butanoate was chosen as the best.

2.4.2 Transesterification of stiripentol wih controlled water activity

Racemic Stirpentol (rac-1) $(10 \mathrm{mg}, 0.042 \mathrm{mmol})$, vinyl butanoate $(0.12 \mathrm{mmol}, 3$ equiv.) and $2.0 \mathrm{~mL}$-hexane were added and stirred in a $4 \mathrm{~mL}$ reaction vial. The salt hydrates $\mathrm{Na}_{2} \mathrm{HPO}_{4}$ x 2 hydrate and $\mathrm{Na}_{2} \mathrm{HPO}_{4}$ x 0 hydrate $\left(0.17 \mathrm{~g}\right.$ of each) were added to give the water activity $\left(\mathrm{a}_{\mathrm{w}}\right)$ value $0.18\left(\right.$ at $\left.35{ }^{\circ} \mathrm{C}\right)$. Lipase A from Candida antarctica $(200 \mathrm{mg})$ was added and the reaction mixture was thermostated at $35{ }^{\circ} \mathrm{C}$. Samples $(10 \mu \mathrm{L})$ were withdrawn, filtered, diluted to $1 \mathrm{~mL}$ and injected on HPLC column at several time intervals.

\subsubsection{Hydrolysis of stiripentol esters}

Stiripentol esters rac-2, rac-3 and rac-4 $(0.077 \mathrm{mmol})$, solvents (acetone or tetrahydrofurane (THF), 0.4 and 1.0 $\mathrm{mL}$, respectively), and phosphate buffer $(1.0 \mathrm{~mL}, 0.1 \mathrm{M}, \mathrm{pH} 7)$ were added to reaction vial $(4 \mathrm{~mL})$. Lipase (CALA and CALB, respectively) (200 mg) was added and the reaction mixture was thermostated at $35{ }^{\circ} \mathrm{C}$. Samples $(10 \mu \mathrm{L})$ of the organic layer were withdrawn at several time intervals, filtered, diluted to $1 \mathrm{~mL}$ and injected on HPLC column.

\subsection{Large scale lipase catalysed transesterification of stiripentol}

Racemic Stiripentol (rac-1) (1 g, $4 \mathrm{mmol}$ ) was dissolved in tert-butyl methyl ether (MTBE) (5 mL) in a $500 \mathrm{~mL}$ round bottom flask and diluted to $200 \mathrm{~mL}$ using n-hexane followed by addition of vinyl butanoate $(1.62 \mathrm{~mL}, 12$ mmol, $1.44 \mathrm{~g}, 3$ eq.) and addition of immobilised Lipase A from Candida antarctica (2 g). The mixture was heated to $35^{\circ} \mathrm{C}$, stirred at $300 \mathrm{rpm}$ and monitored by HPLC. After $106 \mathrm{~h}$, the reaction was stopped by enzyme 
filtration and the solvent together with the excess of vinyl butanoate were evaporated under reduced pressure. The residual $(R)$-ester and $(S)$-alcohol mixture was separated by column chromatography using neutral alumina grade 3 and pet. ether 60-80: $\mathrm{CHCl}_{3}(1: 1, v / v)$ to afford (S)-alcohol ((3S)-1), $(0.4 \mathrm{~g}, 86 \% \text { ee), [a] }]_{\mathrm{D}}-18.1$ (c 10 $\left.\mathrm{CHCl}_{3}\right)$ and $(R)$-butanoate $((3 R)-2),(0.6 \mathrm{~g}, 87 \% e e)$. The $(R)$-butanoate $((3 R)-2)$ was subject to further lipase A catalysed hydrolysis in phosphate buffer $\mathrm{pH} 7.0$ to afford $(R)$-alcohol $((3 R)-1),(0.13 \mathrm{~g}, 94 \% \text { ee), [a }]_{\mathrm{D}}+23.9$ (c 10 $\left.\mathrm{CHCl}_{3}\right)$. The reaction was repeated and stopped after $48 \mathrm{~h}$ to afford the $R-(-)$ - butanoate (3R)-2, $(0.3 \mathrm{~g}, 92 \% e e)$, $[\mathrm{a}]_{\mathrm{D}}-68.0$ for $92 \%$ ee. I. e. lower yield, however, higher $e e$, which may give higher $e e$ of the alcohol after hydrolysis.

\section{Results and Discussion}

Stiripentol rac-1 was prepared in good yields from piperonal and pinacolone followed by reduction using sodium borohydride (Scheme 1). The racemic alcohol 1 was resolved using vinyl butanoate in hexane and catalysed by Lipase A from Candida antarctica (CALA) (Scheme 2). Several lipases were tested for the reaction, but as expected, CALA was the best suited catalyst (Kirk et al., 2002). CALA is in the collection of lipases which exhibit strong restriction on the acid part having a narrow tunnel to accommodate the acyl group, but a wider alcohol binding site (Naik et al., 2010). We have previously demonstrated that substrates with bulky groups around the secondary stereogenic center needs CALA for the desired reaction to take place. (Riise Moen et al., 2007; Fuglseth et al., 2006; Tjosås et al., 2008) The alternative, lipase B, has been shown by Uppenberg et al. (1995) to have a stereospecificity pocket in the active site of limited size. Jacobsen et al. (2000) showed that the maximum size of the small group was three carbons counted from the stereocenter. This pocket accommodates the smaller of the two groups at stereogenic center. For transesterification, five different acyl donors have been used for the CALA catalysed transesterification of racemic Stiripentol ( $r a c-1)$ in n-hexane. Vinyl butanoate gave selective reactions with high rate for ester formation and with an $E$-value of 24. (Figure 1) In order to increase the $E$-value, the water activity was adjusted to $\mathrm{a}_{\mathrm{w}} 0.18$, however, this did not increase the $E$-value. The reaction time was also slowed down by addition of the salt hydrate pairs. Hydrolysis in phosphate buffer and in buffer and co-solvent (50\% THF or $30 \%$ acetone) of the butanoate (rac-2), acetate (rac-3) and propanoate (rac-4) esters catalysed by CALB did not show any conversion after seven days. With CALA as the catalyst the reaction was slow and non-selective. We have previously observed that acetone as a co-solvent in hydrolysis of straight-chained secondary alcohols catalysed by CALB increased the E-value significantly compared to hydrolysis in buffer alone. This co-solvent effect was explained as an enantiospecific inhibition by the liberated alcohol due to increased solubility of the product (Lundhaug et al., 1998). Since no selectivity was observed in similar hydrolysis reactions of Stiripentol esters by CALA even after use of co-solvents, restrictions due to solubility problems of organic substrate and products should be excluded. Further investigations are under way.

The secondary alcohol produced by CALA catalysed hydrolysis of the produced butanoate had optical rotation [a $]_{\mathrm{D}}$ $+23.9\left(\mathrm{c} 10 \mathrm{CHCl}_{3}\right)$ for $94 \%$ ee. Hence the absolute configurations of the faster reacting enantiomer was established as being $(R)$ since it has been reported that $(R)$-Stiripentol has specific optical rotation $[\mathrm{a}]_{\mathrm{D}}+24.9(\mathrm{c}$ $2.61 \mathrm{MeOH}$ ) (Zhang et al., 1994). The slower reacting alcohol showed $[\mathrm{a}]_{\mathrm{D}}-18.1$ (c $10 \mathrm{CHCl}_{3}$ for $86 \%$ ee. The (R)-butanoate eluted as the second isomer in chiral HPLC as compared to the (R)-alcohol, which was the first eluted enantiomer (Figure 2). Also, it showed levorotatory effect $[\mathrm{a}]_{\mathrm{D}}-68.0$ for $92 \%$ ee, whereas the $(R)$-alcohol has a dextrorotatory effect.

We have optimised the simultaneous chiral HPLC separation of Stiripentol (rac-1) and its acetate (rac-3), propanoate (rac-4) and butanoate ( $\mathrm{rac}-2)$ in one run with baseline separation. n-Hexane, 2-propanol (2-PrOH) and/or MTBE have been used as a mobile phase component at different ratios on Chiralcel OD-H column. Examples of separation of rac-1, rac-2 and rac-3 are shown in Figure 2.

\section{Conclusion}

Lipase catalysed enantioselective resolution of Stiripentol through transesterification was performed using lipase A from Candida antarctica, vinyl butanoate as acyl donor and n-hexane as reaction medium. The $E$-value of the resolution was 24, which allowed the isolation of the butanoate (3R)-2 with an enantiomeric excess of $87 \%$ and the alcohol (3S)-1 with $86 \%$ ee. Enzymatic hydrolysis of the ester product gave (3R)-Stiripentol with $94 \%$ ee.

\section{Acknowledgements}

We thank The Research Council of Norway (RCN) for a research fellowship to MFB. (Contract grant number 202903/11).

\section{References}

Anthonsen, H. W., Hoff, B. H., \& Anthonsen, T. (1996). Calculation of enantiomer ratio and equilibrium 
constants in biocatalytic ping-pong bi-bi resolutions. Tetrahedron: Asymmetry, 7, 2633-2638. http://dx.doi.org/10.1016/0957-4166(96)00338-2

Bommarius, A. S., \& Riebel, B. R. Eds. (2004). Biocatalysis. Fundamentals and Applications. Weinheim: Wiley-VCH, ISBN: 3-527-30344-8.

Bornscheuer, U. T., \& Kazlauskas, R. J. (2005). Hydrolases in Organic Synthesis. Regio- and Stereoselective Biotransformations, $\quad\left(2^{\text {nd }} \quad\right.$ ed. $) \quad$ Weinheim: WILEY-VCH, ISBN 3-527-30104-6. http://dx.doi.org/10.1002/3527607544

Casanova, J., \& Conseil, I. (1972). Esters du (methylene-dioxy-3,4 phenyl)-1 dimethyl-4,4 pentene-1 ol-3, leur preparation et leur application en therapeutique. French Pat. 2253504.

Chen, C. S., Fujimoto, Y., Girdaukas, G., \& Sih, C. J. (1982). Quantitative analyses of biochemical kinetic resolutions of enantiomers. J. Am. Chem. Soc., 104, 7294-7299. http://dx.doi.org/10.1021/ja00389a064

Chiron, C. (2005). Stiripentol. Expert Opin. Investig. Drugs, 14, 905-911. http://dx.doi.org/10.1517/13543784.14.7.905

Collins, A. N., Sheldrake, G. N., \& Crosby, J. Eds. (1992). Chirality in Industry. New York: John Wiley \& Sons, ISBN 0-471-93595-6.

Collins, A. N., Sheldrake, G. N., \& Crosby, J. Eds. (1997). Chirality in Industry II. New York: John Wiley \& Sons, ISBN 0-471-96680-0.

Fessner, W.-D., \& Anthonsen, T. Eds. (2009). Modern Biocatalysis. Mörlenbach: Wiley-VCH, ISBN: 978-3-527-32071-4.

Fischer, J. (2009). The anti-convulsant stiripentol acts directly on the GABAA receptor as a positive allosteric modulator. Neuropharmacology, 56, 190-197. http://dx.doi.org/10.1016/j.neuropharm.2008.06.004

Fuglseth, E., Anthonsen, T., \& Hoff, B. H. (2006). New chiral building blocks from Acetovanillone using lipases $\mathrm{A}$ and $\mathrm{B}$ from Candida antarctica. Tetrahedron: Asymmetry, 17, 1290-1295. http://dx.doi.org/10.1016/j.tetasy.2006.04.030

Jacobsen, E. E., Hoff, B. H., \& Anthonsen, T. (2000). Enantiopure derivatives of 1,2-alkanediols: Substrate requirements for lipase B from Candida antarctica. Chirality, 12, 654-659. http://dx.doi.org/10.1002/1520-636X(2000)12:9\%3C654::AID-CHIR2\%3E3.0.CO;2-3

Kirk, O., \& Christensen, M. W. (2002). Lipases from Candida antarctica: Unique Biocatalysts from a Unique Origin. Org. Proc. Res. Dev., 6, 446-451. http://dx.doi.org/10.1021/op0200165

Lundhaug, K., Overbeeke, P. L. A., Jongejan, J., \& Anthonsen, T. (1998). Organic co-solvents restore the inherently high enantiomeric ratio of lipase B from Candida antarctica in hydrolytic resolution by relieving the enantiospecific inhibition of product alcohol. Tetrahedron: Asymmetry, 9, 2851-2856. http://dx.doi.org/10.1016/S0957-4166(98)00273-0

Naik, S., Basu, A., Saikia, R., Madan, B., Paul, P., Chaterjee, R., Brask, J., \& Svendsen, A. (2010). Lipases for use in industrial biocatalysis: Specificity of selected structural groups of lipases. J. Mol. atal., B, 65, 18-23. http://dx.doi.org/10.1016/j.molcatb.2010.01.002

Rakels, J. L. L., Romein, B., Straathof, A. J. J., \& Heinen, J. J. (1994). Kinetic Analysis of Enzymatic Chiral Resolution by Progress Curve Evaluation. Biotechnol. Bioeng., 43, 411-422. http://dx.doi.org/10.1002/bit.260430509

Riise Moen, A., Ruud, K., \& Anthonsen, T. (2007). Chemo-enzymatic synthesis of all isomers of 2-methylbutane-1,2,3,4-tetraol. Important contributors to atmospheric aerosols. Eur. J. Org. Chem., 1262-1266. http://dx.doi.org/10.1002/ejoc.200600873

Sheldon, R. A. (1993). Chirotechnology. New York: Marcel Dekker, Inc. ISBN 0-8247-9143-6.

Tjosås, F., Anthonsen, T., \& Jacobsen, E. E. (2008). Biocatalalytic resolution of saphenic acid. Substrate preferences for lipases A and B from Candida antarctica. ARKIVOC, vi, 81-90.

Trojnar, M. K., Wojtal, K., Trojnar, M. P., \& Czuczwar, S. J. (2005). Stiripentol. A novel antiepileptic drug. Pharmacological Reports, 154-160.

Uppenberg, J., Öhrner, N., Norin, M., Hult, K., Kleywegt, G. J., Patkar, S., Waagen, V., Anthonsen, T., \& Jones, T. A. (1995). Crystallographic and molecular modeling studies of lipase B from Candida antarctica reveal a stereospecificity pocket for secondary alcohols. Biochemistry, 34, 16838-16851. 
http://dx.doi.org/10.1021/bi00051a035

Vallet, F. M. J. (1975). 1-(3,4-Methylenedioxy-phenyl)-4,4-dimethyl-pent-1-en-3-ol. US Pat. 3910959.

Zhang, K. T., Cuyue, R. M., Cui, D., Tombret, F., Botte, H., Lepage, F., Levy, R. H., \& Baillie, T. A. (1994). Metabolic chiral inversion of stiripentol in the rat. I. Mechanistic studies. Drug Metabolism and Disposition, 22, 544-553.

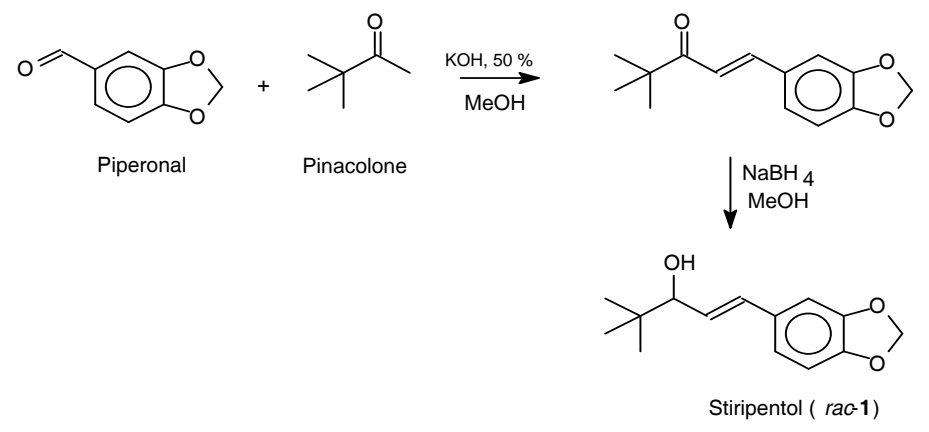

Scheme 1

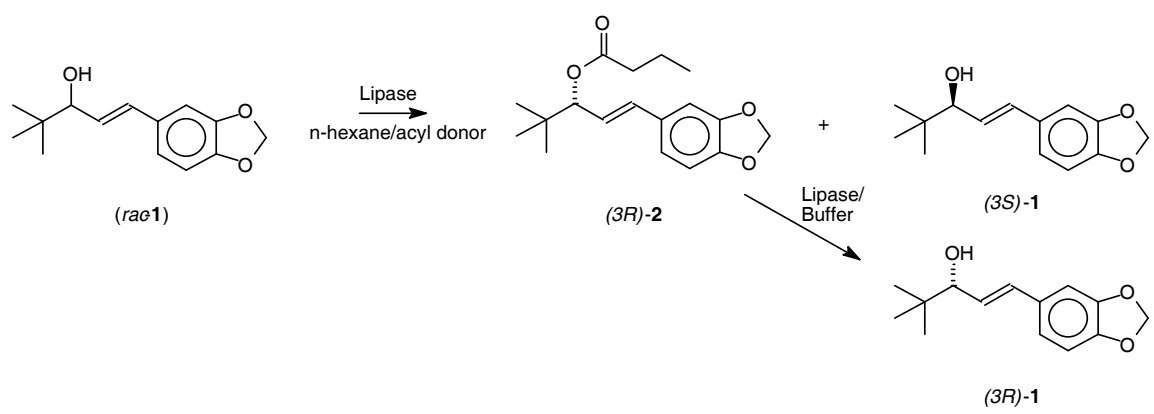

Scheme 2

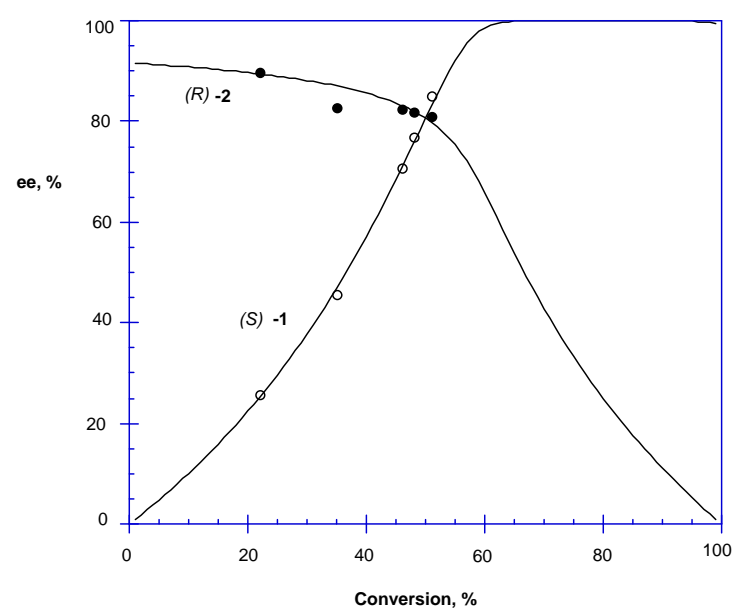

Figure 1. Progress of the kinetic resolution of rac-1 by esterification with vinyl butanoate catalysed by CALA, open circles substrate fraction $(S)-\mathbf{1}$, filled circles product fraction $(R)-\mathbf{2}$ 

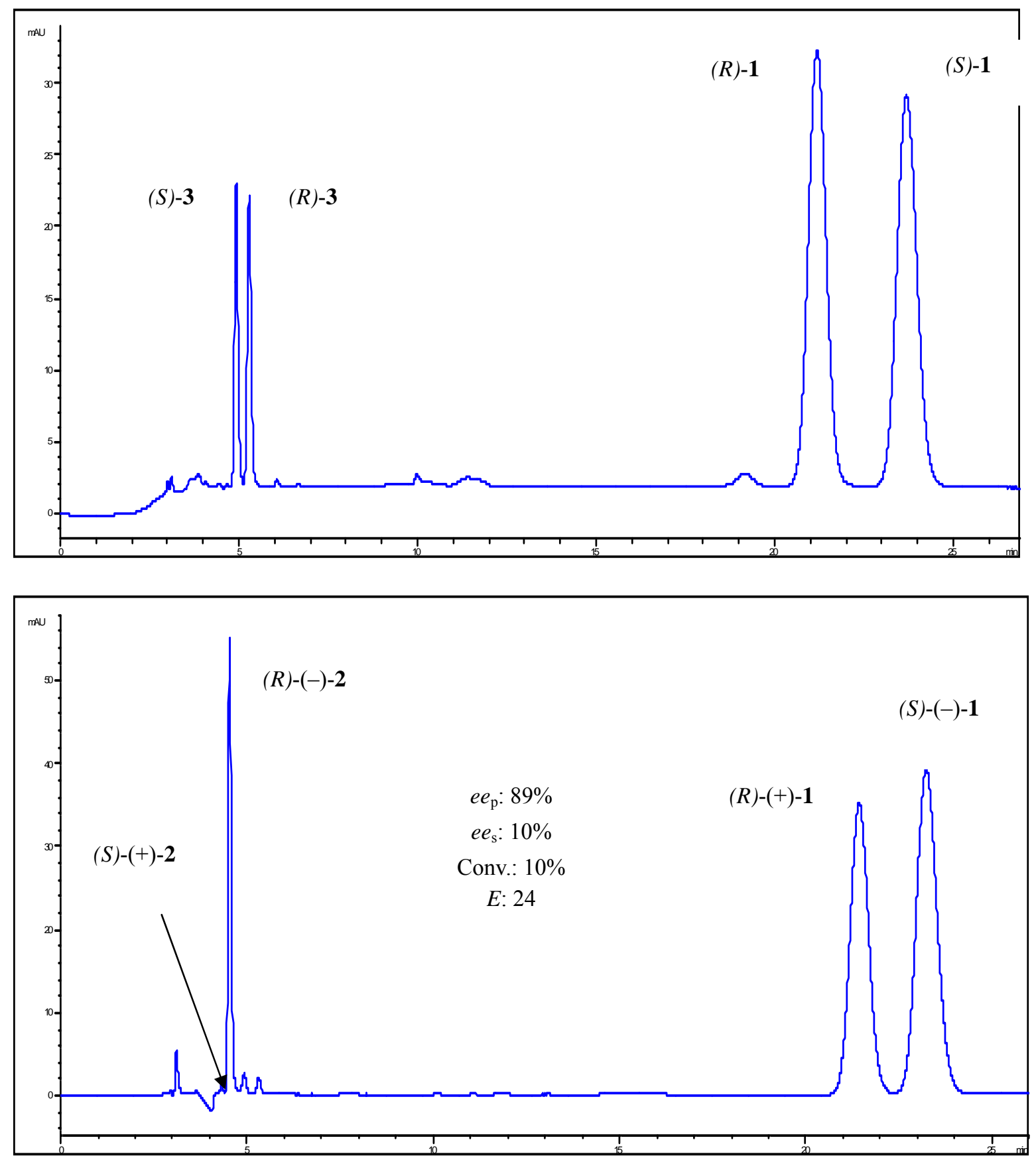

Figure 2. Upper panel: Baseline separation of racemic Stiripentol (rac-1) and its acetate (rac-3) analysed by HPLC using Chiracel OD-H column and mobile phase n-Hexane:MTBE:2-PrOH, 95:5:2 ( $v / v / v)$. Lower panel:

Chromatogram of transesterification reaction of rac-Stiripentol ( $r a c-1)$ with vinyl butanoate after $10 \%$ conversion giving butanoate (-)-2 in $89 \%$ ee 